\title{
PLA2G4A Gene
}

National Cancer Institute

\section{Source}

National Cancer Institute. PLA2G4A Gene. NCI Thesaurus. Code C38588.

This gene plays a role in the regulation of the inflammatory response. 